FORMATION Formation emploi

Revue française de sciences sociales

108 | octobre-décembre 2009

Les processus de professionnalisation

\title{
Processus en cours
}

Jean-Frédéric Vergnies

\section{OpenEdition}

\section{Journals}

Édition électronique

URL : http://journals.openedition.org/formationemploi/2046

DOI : 10.4000/formationemploi.2046

ISSN : 2107-0946

\section{Éditeur}

La Documentation française

\section{Édition imprimée}

Date de publication : 1 décembre 2009

Pagination : 1

ISSN : 0759-6340

\section{Référence électronique}

Jean-Frédéric Vergnies, «Processus en cours », Formation emploi [En ligne], 108 | octobre-décembre 2009, mis en ligne le 17 décembre 2009, consulté le 30 octobre 2020. URL : http://

journals.openedition.org/formationemploi/2046 ; DOI : https://doi.org/10.4000/formationemploi.2046

(C) Tous droits réservés 


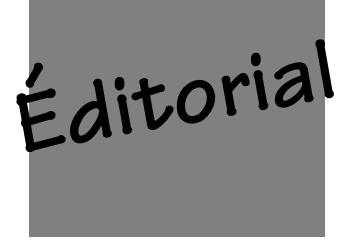

\section{Processus en cours}

'injonction à la professionnalisation est aujourd'hui omniprésente, aussi bien dans la sphère des entreprises et des administrations que dans celle de la formation. Face à cette injonction, la formation et son corollaire, la certification, sont souvent convoquées comme garantes de cette professionnalisation.

Ce dossier de Formation Emploi insiste sur le caractère social et construit de la professionnalisation. Elle est ici envisagée comme un processus.

Ainsi seront évoqués successivement les cas des experts interprètes-traducteurs auprès des tribunaux, par Keltoume Larchet et Jérôme Pélisse ; des salariés au sein du monde du sport dominé par le bénévolat, par Marc Falcoz et Emmanuelle Walter ; des chargés de communication dans l'administration publique, par Dominique Bessières ; d'une association d'anciens salariés face à la fermeture d'une usine, par Delphine Corteel ; de « l'universitarisation » des formations sanitaires et sociales, par Marc Fourdrignier.

En revenant dans la postface sur le concept de professionnalisation, Didier Demazière précise que ce processus est à la fois temporel et social, traversé par des jeux d'acteurs multiples situés dans des contextes économiques évolutifs. Il considère alors la professionnalisation comme « un processus dialectique, impliquant d'une part les travailleurs engagés dans une activité donnée et d'autre part divers acteurs avec lesquels ils interagissent pour accomplir leur travail : hiérarchies de proximité [...], employeurs [...], travailleurs d'autres métiers [...], experts spécialisés [...], clients [...], spécialistes en charge de l'application des réglementations, etc. L'ensemble de ces acteurs forment une configuration professionnelle, plus ou moins complexe et stable selon les cas ».

Hors dossier, Philippe Méhaut et Christopher Winch soulignent la dimension géographique du processus de professionnalisation en étudiant les stratégies nationales d'adaptation au cadre européen des certifications de certains diplômes, dans quatre pays.

Comme la lecture est aussi un processus, bon processus à tous ! 